\title{
Perivascular adipose tissue and coronary atherosclerosis
}

\author{
Jennifer Mancio, Evangelos K. Oikonomou, Charalambos Antoniades*
}

${ }^{1}$ Division of Cardiovascular Medicine, Radcliffe Department of Medicine, University of Oxford, UK.

J.M. and E.K.O. contributed equally to this work.

Word count: 2991

References: 50

*Corresponding author:

Prof. Charalambos Antoniades MD PhD

Professor of Cardiovascular Medicine,

Division of Cardiovascular Medicine University of Oxford,

John Radcliffe Hospital, Oxford OX3 9DU

United Kingdom

Tel: +44-1865-221870

Fax: +44-1865-740352,

e-mail: antoniad@well.ox.ac.uk 


\section{ABSTRACT}

Adipose tissue (AT) is no longer viewed as a passive, energy-storing depot, and a growing body of evidence supports the concept that both quantitative and qualitative aspects of AT are critical in determining an individual's cardiometabolic risk profile. Among all AT sites, perivascular AT (PVAT) has emerged as a depot with a distinctive biological significance in cardiovascular disease given its close anatomical proximity to the vasculature. Recent studies have suggested the presence of complex, bidirectional paracrine and vasocrine signalling pathways between the vascular wall and its PVAT, with far-reaching implications in cardiovascular diagnostics and therapeutics. In this Review, we first discuss the biological role of PVAT in both cardiovascular health and disease, highlighting its dual pro-atherogenic and anti-atherogenic roles, as well as potential therapeutic targets in cardiovascular disease. We then review current evidence and promising new modalities on the non-invasive imaging of epicardial AT and PVAT. Specifically, we present how our expanding knowledge on the bidirectional interplay between the vascular wall and its PVAT can be translated into novel clinical diagnostics tools to assess coronary inflammation. To this end, we present the example of a new computed tomography-based method that tracks spatial changes in PVAT phenotype to extract information about the inflammatory status of the adjacent vasculature, highlighting the numerous diagnostic and therapeutic opportunities that arise from our increased understanding of PVAT biology.

Keywords: Perivascular AT; epicardial AT; pericoronary AT coronary atherosclerosis; computed tomography angiography; attenuation; fat attenuation index, FAI 


\section{INTRODUCTION}

Obesity, traditionally defined as a body mass index $(\mathrm{BMI}) \geq 30 \mathrm{~kg} / \mathrm{m}^{2}$, represents one of the main preventable causes of morbidity and mortality in Western societies. ${ }^{1}$ However, recent large-scale epidemiological studies have questioned the exact nature of this association, revealing a nonlinear, U-shaped association between BMI and all-cause mortality in patients with established cardiovascular disease. ${ }^{2}$ This phenomenon, often described as "obesity paradox", highlights the complex biology of adipose tissue (AT) and its variable effects on the cardiovascular system. BMI, despite its widespread use, fails to take into account variations in AT quality and distribution, which are now established as key determinants of its cardiometabolic effects. ${ }^{3}$ Depot-specific differences in the ability of AT to store lipids as well as its secretome profile are important in understanding the complex association of AT with cardiovascular disease. ${ }^{2}$

Given its anatomical proximity to the vascular wall, perivascular AT (PVAT) has been identified as a key player in both cardiovascular homeostasis and disease. ${ }^{4}$ Contrary to distant AT depots that regulate cardiovascular biology by contributing to a circulating pool of bioactive adipocytokines, PVAT is able to directly modulate key signalling pathways in the vascular wall and myocardium through paracrine and vasocrine routes. ${ }^{5}$ More importantly, we have recently shown that the communication between the vascular wall and PVAT is bi-directional. For instance, locally released inflammatory mediators and/or oxidation products from the diseased vessel can directly modify the phenotype of perivascular adipocytes. ${ }^{6-8}$

In this review, we first describe the anatomy and physiological functions of PVAT, identifying the need for a universal definition that would reflect its distinct biological and imaging characteristics. Next, we discuss the mechanisms by which dysfunctional AT contributes to cardiovascular disease, highlighting the bidirectional communication between the vascular wall and its PVAT, as 
well as promising therapeutic targets related to this axis. Finally, we discuss the diagnostic and possible prognostic value of non-invasive imaging of PVAT, focusing on a recent paradigm shift in our understanding of PVAT as a sensor of vascular inflammation.

\section{The biological role of PVAT in health and disease}

\section{Building a universal definition for PVAT}

Given the absence of an established definition, PVAT is traditionally, and rather crudely, defined as any AT surrounding a blood vessel. This includes peri-aortic fat, as well as organ-specific fat depots located close to major vessels, including the epicardial, pericardial, and peri-renal AT depots. ${ }^{4}$ As with any AT depot, PVAT is composed of various cell types such as adipocytes, preadipocytes, and mesenchymal stem cells, embedded in a matrix that is invested in microvessels. ${ }^{4}$ In humans, PVAT is contiguous with the adventitial layer of the large vessels wall, but it is essentially integrated into the wall of small vessels; it contains predominantly white AT in resistance vessels, whereas large vessels are characterized by both brown and white ATs. ${ }^{45}$ Of all PVAT sites, coronary PVAT is the most widely studied depot, given its close anatomical proximity to the coronary vessels. Nevertheless, the absence of a clear anatomical border has resulted in highly heterogeneous definitions of coronary PVAT in the literature. We have recently proposed a definition of PVAT as any AT within a radial distance from the outer vessel wall equal to the diameter of the adjacent coronary vessel. ${ }^{7}$ This definition is based on a series of histological and gene expression studies that have revealed changing patterns in AT phenotype with increasing distance from the vascular wall, as a result of complex, paracrine vessel-PVAT interactions. ${ }^{7}$ In order to better understand these, a review of the physiological functions of PVAT in health and disease is necessary. 


\section{Physiological function of PVAT in health}

While AT was initially considered to provide exclusively mechanical, metabolic (energy supply and glucose homeostasis) and thermostatic support to the vasculature, in the recent years it has become clear that AT, including PVAT, is also responsible for the secretion of various bioactive molecules, collectively known as adipocytokines. The exact source of these molecules may vary (e.g. cytokines are predominantly produced by inflammatory residing cells in AT, adipokines such as adiponectin as produced mainly by the adipocytes themselves), but they are all critical for the regulation of vascular physiology, including vascular redox state, vascular tone, and endothelial function. ${ }^{4}$ In normal conditions, PVAT exerts anticontractile, anti-inflammatory, and anti-oxidant effects. ${ }^{5910}$ For instance, regulation of vascular tone is dependent on the continuous release of PVAT-derived relaxing factors that enhance vasodilatation via both endothelium-dependent and independent mechanisms. ${ }^{11} 12$ Beyond their effects on vascular tone regulation, adipokines, such as adiponectin and omentin, also exhibit anti-inflammatory and anti-oxidant properties by inhibiting nuclear NF-kB (nuclear factor kappa beta) signalling and NADPH (nicotinamide adenine dinucleotide phosphate)-oxidase activity and restoring endothelial nitric oxidase synthase (eNOS) coupling. 91013

\section{Obesity-induced PVAT remodelling}

In response to excessive caloric intake, AT is forced to expand through adipocyte hyperplasia and/or hypertrophy. This may eventually progress to adipocyte dysfunction and apoptosis, with subsequent inflammatory cell infiltration, late capillary rarefaction and, ultimately, fibrosis. ${ }^{14}$ This AT remodelling generates a systemic chronic, low-grade inflammatory state as a result of a shift 
in the adipocyte phenotype from a protective profile to an imbalanced production of proinflammatory, pro-oxidant and pro-fibrotic adipokines, such as leptin, resistin and visfatin. ${ }^{3}$ Of note, these biological variations are depot-specific. Genome, ${ }^{15}{ }^{16}$ transcriptome, ${ }^{17}$ proteome,${ }^{18}$ and mriRNome ${ }^{19}$-wide expression analyses have identified significant phenotypic differences between EAT and subcutaneous AT (SAT) in CAD patients. Compared to SAT, EAT is characterised by higher expression of pro-inflammatory (tumor necrosis factor- $\alpha$ (TNF- $\alpha$ ), interleukin-6 (IL-6), interleukin 1- $\beta$ (IL1- $\beta$ )), pro-oxidant (NADPH-oxidase, superoxide dismutase-2, catalase, glutathione S-transferase P, protein disulphide isomerase) and angiogenic (vascular endothelial growth factor receptor 1, endothelin 1, angiotensin II receptor 1)-regulatory genes as well as greater infiltration by immune cells, particularly M1 pro-inflammatory macrophages. ${ }^{16} 1820$ Nevertheless, EAT itself is a rather heterogeneous depot, with distinctive transcriptomic signatures around pericoronary, periatrial, and periventricular sites, ${ }^{17}$ highlighting the complex, paracrine interactions between EAT, the coronary vessels and myocardium. A representative summary of the differentially expressed genes or proteins in EAT is presented in Table 1. ${ }^{15-19}$

\section{Vascular disease-induced PVAT remodelling}

We have previously demonstrated that the communication between perivascular adipocytes and the vascular wall is bi-directional, with signals arising from the cardiovascular system modulating adipocyte differentiation and function. ${ }^{6-10}$ Specifically, upregulation of adiponectin expression in PVAT in advanced stages of disease may represent a protective mechanism triggered by increased oxidative stress in the adjacent vasculature (e.g. through lipid peroxidation products that diffuse from the vessel into the surrounding PVAT activating PPAR $\gamma$ [peroxisome proliferator-activated receptor gamma] signalling). In remote AT depots, adiponectin biosynthesis is under the regulation 
of circulating brain natriuretic peptides, a biomarker of heart failure. ${ }^{8}$ This presence of dynamic, phenotypic (morphological and functional) changes in fat composition as a result of its interactions with the cardiovascular system is further supported by experimental studies in mice and pigs. In a mouse model, balloon- or wire-induced vascular injury rapidly induced inflammation and perturbed adipokine gene expression in PVAT. ${ }^{21}$ Similarly, in a porcine model of drug-eluting stent-induced coronary vasoconstriction, PVAT inflammation, as assessed in vivo and in vitro by 18F-fluorodeoxyglucose positron emission tomography (18F-FDG PET), was enhanced at the stent edges compared with control sites. ${ }^{22}$

\section{PVAT as a host of therapeutic targets}

As a result of our increasing understanding of the causal involvement of PVAT in cardiovascular disease pathogenesis, a range of therapeutic targets have been proposed. Potential strategies include the modulation of adipocytokine-mediated signalling pathways through direct administration of adiponectin or specific targeting of its receptors (AdipoR1 and 2). ${ }^{8}$ Another approach is the modulation of more upstream pathways involved in insulin sensitivity and adiponectin biosynthesis regulation, such as PPAR $\gamma$, using thiazolidinediones. ${ }^{23}$ Furthermore, expanding evidence now confirms that both glucagon-like-peptide 1 agonists and dipeptidyl peptidase-4 inhibitors increase adiponectin expression and macrophage polarization, while also promoting AT browning. ${ }^{23}$ Moreover, AT is a source of angiotensinogen contributing to activation of renin-angiotensin-aldosterone system (RAAS), which can be blocked by the widely

used angiotensin-converting enzyme inhibitors and angiotensin-2-receptor blockers. ${ }^{13} 23$ The extent to which these pathways can be modulated in the paracrine PVAT-vessel interactions as well as their potential cardiovascular benefit remain unclear. Scientific advancements in delivery 
methods that specifically target AT may boost research in this field and lead to novel treatment options in cardiovascular therapeutics. ${ }^{25}$

\section{PVAT imaging for cardiovascular risk stratification}

Based on both its biological and close anatomical relationship with the coronary vessels, coronary PVAT imaging may provide useful information for cardiovascular risk stratification. Nevertheless, given the absence of dedicated analysis algorithms, PVAT imaging in most studies has been limited to the crude analysis of total EAT. Indeed, EAT can be easily visualized by routine transthoracic echocardiography and its thickness in the anterior surface of the right ventricle can be measured in a safe and easy manner. ${ }^{26}$ However, the amount of EAT is more accurately and reproducibly quantified by cardiac computed tomography $(\mathrm{CT})$ or magnetic resonance imaging. ${ }^{27}$ Most studies have relied on non-contrast CT scans for EAT segmentation, however coronary CT angiography provides an optimal method of assessing not only the coronary anatomy, but also specific features of coronary PVAT. The relative advantages and limitations of the available imaging methods to assess epicardial and pericoronary AT depots are presented in Table 2.

\section{EAT volume and coronary atherosclerosis}

Several large-scale epidemiological studies conducted in community-based cohorts have explored the importance of EAT volume, such as the Framingham Heart Study, ${ }^{28}{ }^{29}$ MESA (Multi-Ethnic Study of Atherosclerosis), ${ }^{30}$ Heinz Nixdorf Recall Study, ${ }^{31}{ }^{32}$ and Rotterdam Study (Table 3). ${ }^{33}$ These general population cohorts composed of asymptomatic low-risk subjects demonstrated that EAT volume (measured on non-contrast CT scans) was associated with the presence of ischaemic heart disease, ${ }^{29}$ incidence of major adverse cardiovascular events (MACE), ${ }^{32}$ coronary 
calcification, ${ }^{28}{ }^{30}$ and calcium progression. ${ }^{31}$ Furthermore, among participants recruited from hospital registries with low-to intermediate-cardiovascular risk (reflecting the current indications for cardiac CT), higher EAT volumes were positively associated with the presence of coronary stenosis,${ }^{34}$ myocardial ischaemia, ${ }^{35}$ calcified,${ }^{36}$ non-calcified coronary plaques, ${ }^{37}$ as well as highrisk plaque features, such as low-attenuation plaque and thin fibrous cap. However, in the CORE320 (Coronary Artery Evaluation using 320-row Multidetector Computed Tomography Angiography and Myocardial Perfusion) study, Tanami et al. ${ }^{38}$ did not find an independent association between EAT volume and either obstructive CAD, myocardial ischaemia on single photon-emission computed tomography (SPECT) or coronary calcification. Of note, $27 \%$ of CORE320 study population had previously undergone percutaneous coronary intervention, and therefore represented a high-risk population.

It should be highlighted that even though EAT volume has been independently associated with ischaemia and coronary calcification in cross-sectional analyses, ${ }^{28-30}$ as well as with the prospective incidence of adverse events, such as myocardial infarction, ${ }^{32}$ its relationship with CAD may change over the natural history of the disease in response to signals arising from the coronary vasculature, as well as pharmacological and lifestyle interventions, such as weight loss reduction after bariatric surgery, ${ }^{39}$ exercise ${ }^{40}$ and low-calorie diet. ${ }^{41}$ Interestingly, in the SMART (Secondary Manifestations of ARTerial disease) study, Franssens et al. ${ }^{42}$ found that low EAT attenuation on CT was associated with an adverse metabolic profile, and this association was independent of EAT volume, indicating that fat quality measures might add complementary information to that provided by EAT quantity. 


\section{EAT quality and coronary atherosclerosis}

While qualitative characterization of a given AT depot requires direct access to tissue biopsies, non-invasive imaging modalities provide a more practical approach to AT phenotyping in the clinical setting. AT inflammation, a hallmark of dysfunctional AT, can be assessed using PET-CT and has been used to link the metabolic activity of EAT with coronary inflammation (assessed by ${ }^{18} \mathrm{~F}-\mathrm{FDG}$ uptake) ${ }^{43}$ However, PET-CT is limited by poor spatial resolution, and significant background noise due to myocardial uptake of the radiotracer. Simple cardiac CT can provide a qualitative assessment of a given AT depot by means of its attenuation. In order to create a standardised CT-based approach to the qualitative analysis of PVAT, we have recently described a novel metric, namely the Fat Attenuation Index (FAI), that provides a numerical index of AT composition. ${ }^{7}$ FAI was defined as the standardised average attenuation of the AT in a region of interest (within the prespecified window of -190 to -30 Hounsfield Units [HU]) and was inversely associated with adipocyte size and differentiation. ${ }^{7}$ In the past, several studies have assessed the association of EAT attenuation with the overall cardiovascular risk profile and CAD. In the SMART study, Franssens et al. ${ }^{44}$ found a negative association between EAT attenuation and age, BMI, waist circumference, visceral abdominal AT, fasting glucose and insulin resistance, and importantly, these associations were independent of EAT volume, highlighting the different type of information provided by the qualitative AT assessment. In the same cohort, lower EAT attenuation was also associated with coronary artery calcification in men. ${ }^{44}$ Similarly, in 609 asymptomatic low-to intermediate-risk patients, Abazid et al. ${ }^{45}$ observed a negative correlation between EAT attenuation and coronary calcification independent of EAT volume. In contrast, in a cross-sectional analysis of acute myocardial infarction patients and stable CAD controls, Mahabadi et al. ${ }^{27}$ observed a positive association between EAT attenuation and type I acute 
myocardial infarction, while Hell et al. ${ }^{35}$ did not report a link between EAT attenuation and myocardial ischemia on SPECT. These contradicting results may be explained by a small sample size, the variable nature of the study population, as well as methodological limitations, such as selection bias, reverse causality and the presence of confounders that were not taken into account. But the most critical limitation of these studies ${ }^{27} 354445$ remains the analysis of EAT as a homogeneous depot, which ignores the biologically important phenotypic variability of PVAT versus non-PVAT depots in the human heart. ${ }^{17}$

\section{PVAT image phenotyping for detection of cardiovascular disease}

We have recently developed, for the first time, a detailed analysis method of coronary PVAT as a sensor of coronary inflammation and vascular disease, which can be calculated on routine coronary CT angiograms. ${ }^{7}$ This followed the observation that in the presence of coronary inflammation, the release of pro-inflammatory mediators from the vascular wall into the surrounding PVAT blocks the differentiation of perivascular pre-adipocytes into mature, lipid-laden adipocytes. ${ }^{7}$ In patients with $\mathrm{CAD}$, this results in a pericoronary gradient of lipid accumulation and a shift from a greater to a lesser lipophilic content (moving closer to the vascular wall), as evidenced by histological and gene expression analysis of paired EAT biopsies attached to the right coronary artery and $20 \mathrm{~mm}$ away (Figure 2A). ${ }^{7}$ This gradient in adipocyte size and lipid content correlates with a gradient in the CT-measured attenuation (FAI) of pericoronary/epicardial fat from more negative (away from the vascular wall) to less negative Hounsfield Unit values (closer to the vascular wall), which can now be detected using this novel three-dimensional analysis algorithm (Figure 2B). Following extensive validation of this biomarker, we confirmed that perivascular FAI (FAIPVAT) is significantly increased around the coronary vessels of patients with CAD compared to healthy 
controls (Figure 3), as well as around the culprit lesions of acute myocardial infarction patients versus stable lesions from the same patients or patients with stable CAD. ${ }^{7}$ Of note, FAIPVAT appears to track longitudinal changes in coronary inflammation, as evidenced by a significant decrease in FAIPVAT around the culprit lesions in acute myocardial infarction patients five-week after the acute, baseline scan. ${ }^{7}$

Non-invasive detection of coronary inflammation by means of FAIpvat in low-to intermediaterisk subjects could enable the early detection of subclinical CAD, especially among high-risk individuals without visible coronary lesions who are not detected by traditional CT angiography. In patients with established CAD, FAIPVAT could help to assess the inflammatory burden and hence the vulnerability of coronary plaques, identifying those at higher risk of having an acute coronary event and who may benefit from more aggressive medical interventions. To this end, future clinical trials will explore whether PVAT imaging can be used to guide the deployment of expensive therapies targeting inflammation in human atherosclerosis. ${ }^{46}$

Our recent discoveries have been followed by a renewed interest in the non-invasive imaging phenotyping of PVAT. In a per-segment analysis of stable patients with CAD referred for invasive coronary angiography, Marwan et al. ${ }^{47}$ studied 60 coronary segments by intravascular ultrasound in a total of 29 patients and demonstrated that PVAT attenuation was higher around segments with fibrous or lipid-rich plaques, compared to segments without disease. Nevertheless, no difference was found in the pericoronary PVAT attenuation of fibrous versus lipid-rich plaques. More recently, in a study of 27 patients with vasospastic angina and 13 controls, Ohyama et al. ${ }^{48}$ have reported increased adventitial and PVAT inflammation in patients with vasospastic angina, as evidenced by increased PVAT signal on 18F-FDG PET. Other studies have explored the possible association between PVAT and vascular disease in extra-coronary vascular beds. While magnetic 
resonance-derived volumetric features of peri-carotid and peri-aortic PVAT in humans may not be correlated with the local presence of vascular disease, ${ }^{49} \mathrm{CT}$ attenuation of peri-aortic PVAT is positively associated with aortic calcification in a cohort of female patients with systemic lupus erythematosus. ${ }^{50}$ These observations further highlight the importance of qualitative over quantitative features in the assessment of human PVAT.

\section{CONCLUSIONS AND FUTURE DIRECTIONS}

Thanks to its proximity to the coronary vessels, PVAT has emerged as an AT depot with special interest in the cardiovascular field. PVAT is now known to modify local vascular biology through the secretion of adipokines, which exert a range of paracrine effects on the coronary vessels. Both the phenotype and biological effects of PVAT are under the control of complex regulatory

mechanisms, both systemic and local/paracrine. The discovery of a bi-directional interplay between the vascular wall and its PVAT has revealed new pathways with important implications in cardiovascular diagnostics and therapeutics. More recent evidence suggests that PVAT can function as a sensor of coronary inflammation, which can now be detected using a novel CTderived metric, namely FAIPVAT, at no extra cost, or radiation exposure. This tool represents the first major clinical translation of our expanding knowledge on PVAT biology, and could play an important role in improving cardiovascular risk stratification and identifying individuals that would benefit from an ever expanding range of anti-inflammatory and other targeted therapeutic agents in both primary and secondary cardiovascular disease prevention. 


\section{ACKNOWLEDGEMENTS}

Funding: C.A. acknowledges funding by the British Heart Foundation (FS/16/15/32047 and TG/16/3/32687) and the National Institute for Health Research (NIHR) Oxford Biomedical Research Centre. E.K.O. acknowledges funding by the State Scholarships Foundation of Greece (Leonidas Nikolaidis scholarship). This work was supported by the Tripartite Immunometabolism Consortium [TrIC]- Novo Nordisk Foundation; Grant number NNF15CC0018486.

Competing Interests: The methods for analysis of perivascular Fat Attenuation Index (FAI) described in this manuscript are subject to patent applications, numbers PCT/GB2015/052359 and GB1620494.3. C.A. is a founder and shareholder of Caristo Diagnostics, a CT image analysis company.

Author Contributions: J.M. performed the search on the literature database, wrote the manuscript and created the tables. E.K.O. contributed to the writing of the manuscript and created the figures. C.A. gave scientific direction, contributed to writing the manuscript, read and accepted the final version of the manuscript.

Author statement: The Corresponding Author (C.A.) has the right to grant on behalf of all authors and does grant on behalf of all authors, an exclusive licence (or non-exclusive for government employees) on a worldwide basis to the BMJ Publishing Group Ltd and its Licensees to permit this article (if accepted) to be published in HEART editions and any other BMJPGL products to exploit all subsidiary rights. 


\section{FIGURE LEGENDS}

Figure 1: Interactions between adipose tissue (AT) and the coronary vessels. The AT located between the surface of the heart and the visceral layer of the pericardium is defined as epicardial AT (EAT). Contrary to remote AT depots (e.g. pericardial AT, located outside the pericardium) which may affect cardiovascular biology in an endocrine way through the systemic release of adipokines into the circulation, EAT interacts with the adjacent coronary vessels in a paracrine manner. EAT located in close proximity to the vessels is known as perivascular AT (PVAT), and plays a key role in the regulation of cardiovascular health. It has been long established that PVAT can secrete adipokines (e.g. adiponectin) which diffuse directly to the vascular wall, modifying its biology and phenotype. The nature of these effects depends on the secretome of PVAT, which is in turn regulated by both systemic (e.g. insulin resistance, obesity) and local factors (e.g. vascular redox state and inflammatory status). For instance, while adiponectin has been shown to exert antioxidant effects on the vasculature, other adipokines (e.g. resistin, visfatin) are known to promote a pro-oxidant and pro-inflammatory phenotype. More recently, the discovery of "inside-tooutside" signalling pathways has shown that PVAT can also function as a sensor of vascular oxidation and inflammation. In response to inflammatory cytokines (e.g. interleukin-6) and lipid peroxidation products (e.g. 4-hydroxynonenal) released by a diseased vascular segment, local PVAT modifies its composition (decrease in adipocyte size and lipid content) as well as biology

(e.g. increased production of adiponectin, which in turn exerts anti-oxidant effects on the vascular wall in a protective loop mechanism). 
Figure 2. Perivascular adipose tissue phenotyping to detect coronary inflammation. It has recently been demonstrated that in the presence of exogenous inflammatory stimuli, adipocytes lose their ability to differentiate into large, lipid-laden cells (A, left side) and are instead characterized by decreased cell size, lipid accumulation and poor differentiation status (A, right side). This correlates with a shift in the composition of AT from a greater lipophilic to a greater aqueous content, which correlates with a gradient in the attenuation of AT on computed tomography (CT) more negative to less negative Hounsfield Unit (HU) values. In the case of perivascular AT (PVAT), this signifies that in the presence of vascular disease and inflammation, inflammatory mediators released from the vascular wall can induce a concentric gradient of lipid accumulation (lower lipid content closer to the vessel) (B, left side). By applying novel CT analysis tools on routine coronary CT angiograms, we can now track these three-dimensional changes in PVAT phenotype and use them as a dynamic biomarker of the inflammatory status of the adjacent vessel (B, right side).

Figure 3. Gradient of adipocyte size and fat attenuation index (FAI) around the human coronaries in the presence or absence of coronary atherosclerosis. In paired adipose tissue (AT) biopsies of epicardial AT attached to the right coronary artery (RCA) and $\sim 20 \mathrm{~mm}$ away in patients undergoing cardiac surgery, quantification of (A) PPAR- $\gamma$, (B) CEBPA, and (C) FABP4 gene expression and (D) adipocyte size demonstrated an in vivo perivascular gradient of adipocyte differentiation and size. (E to G) In a separate group of patients undergoing clinical computed tomography angiography, FAI around the proximal RCA was calculated in concentric, cylindrical 1-mm-thick layers of pericoronary tissue. (H) FAI mapping of PVAT around the RCA. (I) FAI and radial distance from vascular wall in patients with coronary artery disease (CAD) $(n=149)$ 
versus healthy individuals $(\mathrm{n}=117)$ CEBPA: CCAAT/enhancer binding protein $(\mathrm{C} / \mathrm{EBP}) \alpha$; FABP4: fatty acid binding protein-4; FAI: fat attenuation index; PPAR- $\gamma$ : peroxisome proliferatoractivated receptor gamma; RCA: right coronary artery. Reproduced with permission from Antonopoulos et al. Sci Transl Med. 2017;9(398). 


\section{TABLES}

Table 1: Overview of experimental studies in human pericoronary adipose tissue (PVAT) and vascular disease.

\begin{tabular}{|c|c|c|c|}
\hline Authors & Experimental Design & Analysis & Main Findings \\
\hline $\begin{array}{l}\text { Mazurek } \\
\text { T., US } \\
2003^{15}\end{array}$ & $\begin{array}{l}42 \text { paired PVAT (around the } \\
\text { right coronary artery) and SAT } \\
\text { samples in patients with CAD } \\
\text { who underwent elective } \\
\text { CABG }\end{array}$ & Genome & $\begin{array}{l}\text { - EAT exhibited significantly higher levels of chemokine } \\
\text { (MCP-1) and several inflammatory cytokines (IL-1, IL-6, } \\
\text { IL-6sR, and TNF-alpha) than SAT } \\
\text { - Local inflammatory burden may not correlate with plasma } \\
\text { concentrations of circulating cytokines } \\
\text { - EAT inflammation was independent of several clinical } \\
\text { variables (obesity, diabetes, or chronic therapy with statins } \\
\text { or ACE inhibitors). }\end{array}$ \\
\hline $\begin{array}{l}\text { Chatterjee } \\
\text { TK., US } \\
2013^{16}\end{array}$ & $\begin{array}{l}6 \text { paired PVAT (around the } \\
\text { left coronary artery artery) and } \\
\text { SAT samples collected from } \\
\text { human organ donors without } \\
\text { diabetes or metabolic diseases }\end{array}$ & Genome & $\begin{array}{l}\text { - } 156 \text { upregulated genes in PVAT vs. SAT, } 59 \text { associated } \\
\text { with angiogenesis, vascular biology or inflammation, which } \\
\text { include TNFRSF11B (osteoprotegerin), PLAT, TGFB1, } \\
\text { THBS2, HIF1, GATA6, SERPINE1 } \\
\text { - } 166 \text { downregulated genes in PVAT vs. SAT, } 21 \text { associated } \\
\text { with vascular and inflammation including ANGPT1, } \\
\text { ANGPTL1, and VEGFC }\end{array}$ \\
\hline $\begin{array}{l}\text { Gaborit } \\
\text { B., France } \\
2015^{17}\end{array}$ & $\begin{array}{l}41 \text { paired EAT and SAT } \\
\text { samples } \\
\text { EAT samples collected from } \\
\text { matched patients with CAD } \\
\text { and AF from PVAT } \\
\text { ("pericoronary" } \quad(\mathrm{n}=15), \\
\text { periatrial }(\mathrm{n}=10) \text {, peri-right } \\
\text { ventricle }(\mathrm{n}=16))\end{array}$ & Transcri] & $\begin{array}{l}\text { - Genes overexpressed in PVAT were implicated in } \\
\text { proliferation, O-N glycan biosynthesis, and sphingolipid } \\
\text { metabolism } \\
\text { - Peri-atrial EAT displayed an atypical pattern with genes } \\
\text { implicated in cardiac muscle contraction and intracellular } \\
\text { calcium signalling pathways }\end{array}$ \\
\hline $\begin{array}{l}\text { Salgado- } \\
\text { Somoza } \\
\text { A., Spain } \\
2010^{18}\end{array}$ & $\begin{array}{l}11 \text { paired EAT and SAT } \\
\text { samples in patients with CAD } \\
\text { who underwent elective } \\
\text { CABG }\end{array}$ & Proteome & $\begin{array}{l}\text { - ROS production was higher in EAT than SAT } \\
\text { - Catalase levels were lower in EAT than in SAT } \\
\text { - EAT differed from SAT in the post-transcriptional profiles } \\
\text { of oxidative stress-related proteins such as PDIA1, GSRP1 } \\
\text { and PGAM1 }\end{array}$ \\
\hline $\begin{array}{l}\text { Vacca M., } \\
\text { Italy } \\
2015^{19}\end{array}$ & $\begin{array}{l}44 \text { paired EAT and SAT } \\
\text { samples from CAD patients } \\
(93 \% \quad \text { with } \quad \text { metabolic } \\
\text { syndrome } \quad(n=29) \quad \text { and } \\
\text { controls } \quad(\text { metabolically } \\
\text { healthy patients without CAD) } \\
(\mathrm{n}=15)\end{array}$ & $\begin{array}{l}\text { Whole } \\
\text { genome } \\
\text { microarrays } \\
\text { miRNA }\end{array}$ & $\begin{array}{l}\text { - miR-103-3p levels aresuppressed in EAT of CAD patients } \\
\text { - CCL13 circulating levels were increased in CAD patients }\end{array}$ \\
\hline
\end{tabular}

ACE: angiotensin-converting enzyme, AF: atrial fibrillation, AT: adipose tissue, CABG: coronary artery bypass grafting, CAD: coronary artery disease, CCL-13: chemokine ligand 13, EAT: epicardial adipose tissue, GSRP1: glutathione S-transferase P1, PDIA1: protein disulfide isomerase, PGAM1: phosphoglycerate mutase 1, PVAT: perivascular adipose tissue, SAT: subcutaneous adipose tissue, ROS: reactive oxygen species. 
Table 2: Imaging modalities for assessing epicardial and pericoronary adipose tissue (PVAT) quantity and quality.

\begin{tabular}{|c|c|c|c|c|}
\hline Imaging modality & Fat imaged & Measurements & Advantages & Disadvantages \\
\hline $\begin{array}{l}\text { Transthoracic } \\
\text { Echocardiography }\end{array}$ & - EAT & $\begin{array}{l}\text { - Quantity: } \\
\text { Thickness }\end{array}$ & $\begin{array}{l}\text { - Innocuous } \\
\text { - Routinely performed } \\
\text { - Ease and quick to } \\
\text { obtain } \\
\text { - Inexpensive }\end{array}$ & $\begin{array}{l}\text { - Low spatial resolution } \\
\text { - 2-D measurement at single } \\
\text { point } \\
\text { - Poor reproducibility } \\
\text { - Limited by the quality of } \\
\text { acoustic window and by the } \\
\text { presence of pericardial } \\
\text { effusion }\end{array}$ \\
\hline $\begin{array}{l}\text { Non-contrast } \\
\text { Computed } \\
\text { Tomography }\end{array}$ & - EAT & $\begin{array}{l}\text {-Quantity: } \\
\text { Thickness, area, } \\
\text { volume } \\
\text { - Quality: } \\
\text { Attenuation }\end{array}$ & $\begin{array}{l}\text { - Volumetric } \\
\text { - IV contrast } \\
\text { administration is not } \\
\text { required }\end{array}$ & $\begin{array}{l}\text { - Radiation exposure } \\
\text { - PVAT cannot be assessed }\end{array}$ \\
\hline $\begin{array}{l}\text { Computed } \\
\text { Tomography } \\
\text { Angiography }\end{array}$ & $\begin{array}{l}\cdot \mathrm{PVAT} \\
\cdot \mathrm{EAT}\end{array}$ & $\begin{array}{l}\text {-Quantity: } \\
\text { Thickness, area, } \\
\text { volume } \\
\text { - Quality: } \\
\text { Attenuation }\end{array}$ & $\begin{array}{l}\text { - Volumetric } \\
\text { - High spatial resolution } \\
\text { - Offer PVAT } \\
\text { assessment }\end{array}$ & $\begin{array}{l}\text { - Radiation exposure } \\
\text { - IV iodinated contrast } \\
\text { required }\end{array}$ \\
\hline $\begin{array}{l}\text { Magnetic } \\
\text { Resonance } \\
\text { Imaging }\end{array}$ & $\begin{array}{l}\text { - PVAT } \\
\text { - EAT }\end{array}$ & $\begin{array}{l}\text { - Quantity: } \\
\text { Thickness, area, } \\
\text { volume } \\
\text { - Quality: Proton } \\
\text { density fat fraction }\end{array}$ & $\begin{array}{l}\text { - Volumetric } \\
\text { - No radiation exposure } \\
\text { - No iodinated contrast } \\
\text { - Can be coupled with } \mathrm{H}^{1} \\
\text { spectroscopy }\end{array}$ & $\begin{array}{l}\text { - Limited availability } \\
\text { - High cost } \\
\text { - Inferior spatial resolution } \\
\text { than CT } \\
\text { - Time-consuming } \\
\text { - Less tolerable by patients }\end{array}$ \\
\hline $\begin{array}{l}18 \mathrm{~F}- \\
\text { fluorodeoxyglucos } \\
\text { e PET/CT }\end{array}$ & $\begin{array}{l}\cdot \mathrm{PVAT} \\
\cdot \mathrm{EAT}\end{array}$ & $\begin{array}{l}\text { - Quality: } \\
\text { Inflammatory/meta } \\
\text { bolic activity } \\
\text { measured based on } \\
\text { radiotracer uptake }\end{array}$ & $\begin{array}{l}\text { - Functional } \\
\text { - High sensitivity }\end{array}$ & $\begin{array}{l}\text { - Radiation exposition } \\
\text { - Specificity for inflammation } \\
\text { is not clearly defined with all } \\
\text { agents } \\
\text { - Interference by radiotracer } \\
\text { presence in the blood pool and } \\
\text { surrounding tissues }\end{array}$ \\
\hline
\end{tabular}

CT: computed tomography, EAT: epicardial adipose tissue, FDG: F-fluorodeoxyglucose, IV: intravenous, PET: positron emission tomography, PVAT: perivascular adipose tissue. 
Table 3: Overview of studies reporting the association between EAT volume on CT and coronary atherosclerosis.

\begin{tabular}{|c|c|c|c|c|c|c|c|c|c|}
\hline Authors & $\begin{array}{l}\text { Study } \\
\text { design }\end{array}$ & $\begin{array}{l}\text { Study } \\
\text { Population }\end{array}$ & $\begin{array}{l}\text { No. of } \\
\text { Subjects }\end{array}$ & $\begin{array}{l}\text { Male } \\
(\%)\end{array}$ & $\begin{array}{l}\text { Age } \\
\text { Mean } \pm \text { SD } \\
\text { (Years) }\end{array}$ & $\begin{array}{l}\text { CAD } \\
\text { Outcomes }\end{array}$ & Main Findings & $\begin{array}{l}\text { Variables Included } \\
\text { in the Multiple Models }\end{array}$ & $\begin{array}{l}\text { Quality } \\
\text { MINORS } \\
\text { Score } \\
\end{array}$ \\
\hline \multicolumn{10}{|c|}{ A. General Population-based Studies } \\
\hline \multicolumn{10}{|c|}{ i) Cross-sectional associations } \\
\hline $\begin{array}{l}\text { Mahabadi } \\
\text { A.A. et al. } \\
\text { US } \\
2009^{29}\end{array}$ & $\begin{array}{l}\text { Cross- } \\
\text { section } \\
\text { al }\end{array}$ & $\begin{array}{l}\text { Framingham } \\
\text { Heart Study }\end{array}$ & 1267 & 46 & $60 \pm 9$ & $\begin{array}{l}\text { CHD (MI, stable } \\
\text { or unstable } \\
\text { angina), stroke } \\
\text { (ischaemic or } \\
\text { haemorragic), } \\
\text { intermittent } \\
\text { claudication, } \\
\text { congestive heart } \\
\text { failure }\end{array}$ & $\begin{array}{l}\text { - EAT volume was associated with } \\
\text { cardiovascular disease independently of } \\
\text { BMI and WC, but not after adjustment for } \\
\text { traditional cardiovascular risk factors } \\
\text { - There was no significant interaction with } \\
\text { gender }\end{array}$ & $\begin{array}{l}\text { Age, gender, BMI, WC }+ \text { systolic } \\
\text { blood pressure, hypertensive } \\
\text { medication, diabetes, total/HDL } \\
\text { cholesterol lipid treatment, } \\
\text { smoking, alcohol, menopausal } \\
\text { status, and hormone replacement } \\
\text { therapy }\end{array}$ & $\begin{array}{l}14 \\
\text { (out of 16) }\end{array}$ \\
\hline $\begin{array}{l}\text { Rosito, G. } \\
\text { et al., US } \\
2009^{28}\end{array}$ & $\begin{array}{l}\text { Cross- } \\
\text { section } \\
\text { al }\end{array}$ & $\begin{array}{l}\text { Framingham } \\
\text { Heart Study }\end{array}$ & 1155 & 45 & $\begin{array}{l}W: 63 \pm 9 \\
M: 63 \pm 9\end{array}$ & $\mathrm{CAC}$ & $\begin{array}{l}\text { - There was an independent correlation } \\
\text { between EAT volume and CAC } \\
\text { - A significant interaction with gender was } \\
\text { found with EAT being associated with a } \\
\text { more adverse risk factor profile in females } \\
\text { than males }\end{array}$ & $\begin{array}{l}\text { Age, gender, systolic blood } \\
\text { pressure, hypertensive medication, } \\
\text { diabetes, total/HDL cholesterol } \\
\text { lipid treatment, smoking, alcohol, } \\
\text { menopausal status, and hormone } \\
\text { replacement therapy + BMI, VAF } \\
\text { and WC }\end{array}$ & $\begin{array}{l}14 \\
\text { (out of 16) }\end{array}$ \\
\hline $\begin{array}{l}\text { McClain, } \\
\text { J. et al., } \\
\text { US } \\
2013^{30}\end{array}$ & $\begin{array}{l}\text { Cross- } \\
\text { section } \\
\text { al }\end{array}$ & MESA study & 6814 & 48 & $45-84$ & CAC & $\begin{array}{l}\text { - EAT volume was associated with the } \\
\text { presence and severity of CAC, but these } \\
\text { associations did not remain significant after } \\
\text { adjustment for BMI } \\
\text { - No significant interaction was found with } \\
\text { gender or race/ethnicity }\end{array}$ & $\begin{array}{l}\text { Age, square age, gender, } \\
\text { race/ethnicity, smoking, physical } \\
\text { activity, alcohol, education + BMI }\end{array}$ & $\begin{array}{l}14 \\
\text { (out of } 16 \text { ) }\end{array}$ \\
\hline $\begin{array}{l}\text { Bos, D. et } \\
\text { al., The } \\
\text { Netheraln } \\
\text { ds, } 2015^{33}\end{array}$ & $\begin{array}{l}\text { Cross- } \\
\text { section } \\
\text { al }\end{array}$ & $\begin{array}{l}\text { Rotterdam } \\
\text { study }\end{array}$ & 2298 & 52 & $69 \pm 6.6$ & CAC & $\begin{array}{l}\text { EAT volume was independently } \\
\text { associated with coronary calcification in } \\
\text { men, but not in women. }\end{array}$ & $\begin{array}{l}\text { Age, waist circumference, systolic } \\
\text { blood pressure, diastolic blood } \\
\text { ressure, use of blood pressure- } \\
\text { lowering medication. Serum total } \\
\text { cholesterol, serum HDL } \\
\text { cholesterol, use of lipid-lowering } \\
\text { medication, diabetes, and smoking } \\
\text { status }\end{array}$ & $\begin{array}{l}14 \text { (out of } \\
16)\end{array}$ \\
\hline
\end{tabular}




\begin{tabular}{|c|c|c|c|c|c|c|c|c|c|}
\hline $\begin{array}{l}\text { Mahabadi } \\
\text { A.A. et } \\
\text { al., } \\
\text { Germany, } \\
2013^{32}\end{array}$ & $\begin{array}{l}\text { Prospec } \\
\text { tive } \\
\text { Cohort }\end{array}$ & $\begin{array}{l}\text { Heinz Nixdorf } \\
\text { Recall Study }\end{array}$ & 4093 & 47 & $59 \pm 8$ & MACE & $\begin{array}{l}\text { - During the median follow-up of } 8 \pm 1.5 \text { yrs, } \\
\text { doubling EAT volume was associated with } \\
\text { more than 2-fold increase of risk of } \\
\text { coronary events beyond traditional } \\
\text { cardiovascular risk factors } \\
\text { - After further adjustment for CAC, EAT } \\
\text { volume remained a significant predictor of } \\
\text { MACE }\end{array}$ & $\begin{array}{l}\text { Age, gender, WC, systolic and } \\
\text { diastolic blood } \begin{array}{r}\text { pressure, } \\
\text { antihypertensive } \\
\text { LDL-C, HDL-C, lipid-lowering }\end{array} \\
\text { medication, diabetes, smoking }\end{array}$ & $\begin{array}{l}16 \\
\text { (out of 16) }\end{array}$ \\
\hline $\begin{array}{l}\text { Mahabadi } \\
\text { A. A. et } \\
\text { al., } \\
\text { Germany, } \\
2014^{31}\end{array}$ & $\begin{array}{l}\text { Prospec } \\
\text { tive } \\
\text { Cohort }\end{array}$ & $\begin{array}{l}\text { Heinz Nixdorf } \\
\text { Recall Study }\end{array}$ & 3367 & 47 & $59 \pm 8$ & $\begin{array}{l}\text { CAC } \\
\text { progression }\end{array}$ & $\begin{array}{l}\text { - EAT volume was higher in subjects with } \\
\text { CAC progression, and this association was } \\
\text { independent of traditional cardiovascular } \\
\text { risk factors in young, non-obese and low } \\
\text { CAC-subjects }\end{array}$ & $\begin{array}{l}\text { Age, gender, BMI, systolic blood } \\
\text { pressure, antihypertensive } \\
\text { medication, LDL-C, HDL-C, } \\
\text { lipid-lowering medication, } \\
\text { triglycerides, diabetes, smoking } \\
\text { status }\end{array}$ & $\begin{array}{l}16 \\
\text { (out of 16) }\end{array}$ \\
\hline \multicolumn{10}{|c|}{ B. Hospital-based Studies } \\
\hline $\begin{array}{l}\text { Versteyle } \\
\text { n M. O. et } \\
\text { al., 2012, } \\
\text { Netherlan } \\
\mathrm{d}^{34}\end{array}$ & $\begin{array}{l}\text { Cross- } \\
\text { section } \\
\text { al }\end{array}$ & $\begin{array}{l}\text { Intermediate- } \\
\text { risk of CAD }\end{array}$ & 410 & 49 & $57 \pm 11.0$ & $\begin{array}{l}\text { Moderate and } \\
\text { severe coronary } \\
\text { stenosis }\end{array}$ & $\begin{array}{l}\text { - Diabetic patients had higher EAT volume } \\
\text { than non-diabetic individuals } \\
\text { independently of BMI } \\
\text { - In crude analysis, EAT volume was } \\
\text { associated with the presence and extent of } \\
\text { CAD in diabetic and non-diabetic patients, } \\
\text { but these associations did not remain } \\
\text { significant following adjustment for } \\
\text { confounders }\end{array}$ & $\begin{array}{l}\text { Age, gender, systolic blood } \\
\text { pressure, smoking }\end{array}$ & $\begin{array}{l}18 \\
\text { (out of 24) }\end{array}$ \\
\hline $\begin{array}{l}\text { Hell, M. } \\
\text { et al., US, } \\
2016^{35}\end{array}$ & $\begin{array}{l}\text { Cross- } \\
\text { section } \\
\text { al }\end{array}$ & $\begin{array}{l}\text { Subjects with } \\
\text { and without } \\
\text { ischemia from } \\
\text { the EISNER } \\
\text { Registry }\end{array}$ & $\begin{array}{l}213 \\
\text { Ischaemi } \\
\text { a: } 71 \\
\text { C: } 142\end{array}$ & 90 & $60 \pm 9.9$ & $\begin{array}{l}\text { Myocardial } \\
\text { ischaemia }\end{array}$ & $\begin{array}{l}\text { - Patients with myocardial ischaemia had } \\
\text { higher volumes of EAT, and EAT increased } \\
\text { the diagnostic accuracy of CT above CAC } \\
\text { score }\end{array}$ & $\begin{array}{l}\text { Age, gender, presence of } \\
\text { symptoms and traditional } \\
\text { cardiovascular risk factors }\end{array}$ & $\begin{array}{l}10 \\
\text { (out of } 16 \text { ) }\end{array}$ \\
\hline $\begin{array}{l}\text { Bettencou } \\
\text { rt, N. et } \\
\text { al., 2012, } \\
\text { Portugal }^{3} \\
6\end{array}$ & $\begin{array}{l}\text { Cross- } \\
\text { section } \\
\text { al }\end{array}$ & $\begin{array}{l}\text { Intermediate- } \\
\text { risk of CAD }\end{array}$ & 215 & 61 & $58 \pm 11.0$ & $\begin{array}{l}\text { Coronary } \\
\text { calcification }\end{array}$ & $\begin{array}{l}\text { - EAT volume was correlated with coronary } \\
\text { calcification independently of abdominal } \\
\text { VAT } \\
\text { - EAT was associated with an additional } \\
\text { increase of } 8 \% \text { in men when compared } \\
\text { women. }\end{array}$ & $\begin{array}{l}\text { Age, gender, BMI, visceral } \\
\text { abdominal fat, hypertension, } \\
\text { dyslipidemia, diabetes mellitus, } \\
\text { smoking }\end{array}$ & $\begin{array}{l}18 \\
\text { (out of 24) }\end{array}$ \\
\hline $\begin{array}{l}\text { Ito, T. et } \\
\text { al., } 2013 \\
\text { Japan }^{37}\end{array}$ & $\begin{array}{l}\text { Cross- } \\
\text { section } \\
\text { al }\end{array}$ & $\begin{array}{l}\text { Very low-risk } \\
\text { patients with } \\
\text { CAC equal } \\
\text { zero }\end{array}$ & 1308 & 46 & $59 \pm 12.3$ & $\begin{array}{l}\text { Non-calcified } \\
\text { coronary } \\
\text { plaques }\end{array}$ & $\begin{array}{l}\text { - EAT volume was higher in patients with } \\
\text { obstructive non-calcified plaques (adj-OR, } \\
95 \% \text { CI: } 1.10,1.04-1.16 \text { ) or vulnerable } \\
\text { plaques (adj-OR, } 95 \% \text { CI: } 1.19,1.12-1.27 \text { ) }\end{array}$ & $\begin{array}{l}\text { Age, gender, hypertension, } \\
\text { diabetes, typical symptoms }\end{array}$ & $\begin{array}{l}12 \\
\text { (out of 16) }\end{array}$ \\
\hline
\end{tabular}


- EAT volume increased the diagnostic

accuracy of Framingham Risk Score for the

detection of obstructive non-calcified

\begin{tabular}{|c|c|c|c|c|c|c|c|c|}
\hline $\begin{array}{l}\text { Tanami, } \\
\text { Y. et al., } \\
\text { US, } \\
2015^{38}\end{array}$ & $\begin{array}{l}\text { Cross- } \\
\text { section } \\
\text { al }\end{array}$ & $\begin{array}{l}\text { Intermediate } \\
\text { to high-risk } \\
\text { patients } \\
\text { referred to } \\
\text { CTA from the } \\
\text { CORE320 } \\
\text { Study }\end{array}$ & 380 & 66 & $62 *$ & $\begin{array}{l}\text { Coronary } \\
\text { stenosis, CAC, } \\
\text { myocardial } \\
\text { ischaemia }\end{array}$ & $\begin{array}{l}\text { - There was a significant association } \\
\text { between EAT volume and CAC in crude } \\
\text { analysis, which did not remain significant } \\
\text { in adjusted models } \\
\text { - EAT volume was not associated with the } \\
\text { presence of coronary stenosis or myocardial } \\
\text { ischaemia }\end{array}$ & $\begin{array}{l}\text { Age, gender, race, BMI, } 10 \\
\text { hypertension, dyslipidemia, } \\
\text { family history of CAD, previous }\end{array}$ \\
\hline
\end{tabular}

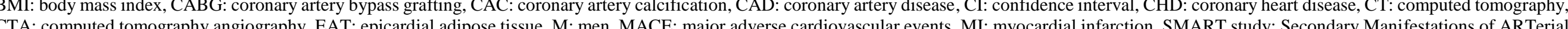

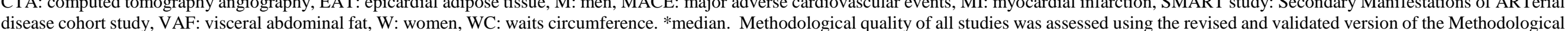

Index for Non-Randomized Studies (MINORS). 


\section{REFERENCES}

1. Whitlock G, Lewington S, Sherliker P, et al. Body-mass index and cause-specific mortality in 900000 adults: collaborative analyses of 57 prospective studies. Lancet 2009;373(9669):1083-96. doi: 10.1016/s01406736(09)60318-4 [published Online First: 2009/03/21]

2. Antonopoulos AS, Oikonomou EK, Antoniades C, et al. From the BMI paradox to the obesity paradox: the obesity-mortality association in coronary heart disease. Obes Rev 2016;17(10):989-1000. doi: 10.1111/obr.12440 [published Online First: 2016/07/14]

3. Fuster JJ, Ouchi N, Gokce N, et al. Obesity-Induced Changes in Adipose Tissue Microenvironment and Their Impact on Cardiovascular Disease. Circ Res 2016;118(11):1786-807. doi: 10.1161/circresaha.115.306885 [published Online First: 2016/05/28]

4. Britton KA, Fox CS. Perivascular adipose tissue and vascular disease. Clin Lipidol 2011;6(1):79-91. doi: 10.2217/clp.10.89 [published Online First: 2011/06/21]

5. Akoumianakis I, Antoniades C. The interplay between adipose tissue and the cardiovascular system: is fat always bad? Cardiovasc Res 2017;113(9):999-1008. doi: 10.1093/cvr/cvx111 [published Online First: 2017/06/06]

6. Antonopoulos AS, Margaritis M, Verheule S, et al. Mutual Regulation of Epicardial Adipose Tissue and Myocardial Redox State by PPAR-gamma/Adiponectin Signalling. Circ Res 2016;118(5):842-55. doi: 10.1161/CIRCRESAHA.115.307856

7. Antonopoulos AS, Sanna F, Sabharwal N, et al. Detecting human coronary inflammation by imaging perivascular fat. Sci Transl Med 2017;9(398) doi: 10.1126/scitranslmed.aal2658

8. Antonopoulos AS, Margaritis M, Coutinho P, et al. Reciprocal effects of systemic inflammation and brain natriuretic peptide on adiponectin biosynthesis in adipose tissue of patients with ischemic heart disease. Arterioscler Thromb Vasc Biol 2014;34(9):2151-9. doi: 10.1161/atvbaha.114.303828 [published Online First: 2014/07/26]

9. Antonopoulos AS, Margaritis M, Coutinho P, et al. Adiponectin as a link between type 2 diabetes and vascular NADPH oxidase activity in the human arterial wall: the regulatory role of perivascular adipose tissue.

Diabetes 2015;64(6):2207-19. doi: 10.2337/db14-1011 
10. Margaritis M, Antonopoulos AS, Digby J, et al. Interactions between vascular wall and perivascular adipose tissue reveal novel roles for adiponectin in the regulation of endothelial nitric oxide synthase function in human vessels. Circulation 2013;127(22):2209-21. doi: 10.1161/CIRCULATIONAHA.112.001133

11. Gollasch M. Vasodilator signals from perivascular adipose tissue. Br J Pharmacol 2012;165(3):633-42. doi: 10.1111/j.1476-5381.2011.01430.x

12. Chang L, Xiong W, Zhao X, et al. Bmall in Perivascular Adipose Tissue Regulates Resting Phase Blood Pressure Through Transcriptional Regulation of Angiotensinogen. Circulation 2018 doi: 10.1161/CIRCULATIONAHA.117.029972

13. Akoumianakis I, Akawi N, Antoniades C. Exploring the Crosstalk between Adipose Tissue and the Cardiovascular System. Korean Circ J 2017;47(5):670-85. doi: 10.4070/kcj.2017.0041 [published Online First: 2017/09/29]

14. Goossens GH, Bizzarri A, Venteclef N, et al. Increased adipose tissue oxygen tension in obese compared with lean men is accompanied by insulin resistance, impaired adipose tissue capillarization, and inflammation. Circulation 2011;124(1):67-76. doi: 10.1161/circulationaha.111.027813 [published Online First: 2011/06/15]

15. Mazurek T, Zhang L, Zalewski A, et al. Human epicardial adipose tissue is a source of inflammatory mediators. Circulation 2003;108(20):2460-6. doi: 10.1161/01.cir.0000099542.57313.c5 [published Online First: 2003/10/29]

16. Chatterjee TK, Aronow BJ, Tong WS, et al. Human coronary artery perivascular adipocytes overexpress genes responsible for regulating vascular morphology, inflammation, and hemostasis. Physiol Genomics 2013;45(16):697-709. doi: 10.1152/physiolgenomics.00042.2013 [published Online First: 2013/06/06]

17. Gaborit B, Venteclef N, Ancel P, et al. Human epicardial adipose tissue has a specific transcriptomic signature depending on its anatomical peri-atrial, peri-ventricular, or peri-coronary location. Cardiovasc Res 2015;108(1):62-73. doi: 10.1093/cvr/cvv208

18. Salgado-Somoza A, Teijeira-Fernandez E, Fernandez AL, et al. Proteomic analysis of epicardial and subcutaneous adipose tissue reveals differences in proteins involved in oxidative stress. Am J Physiol 
Heart Circ Physiol 2010;299(1):H202-9. doi: 10.1152/ajpheart.00120.2010 [published Online First: 2010/05/04]

19. Vacca M, Di Eusanio M, Cariello M, et al. Integrative miRNA and Whole-Genome Analyses of Epicardial Adipose Tissue in Patients with Coronary Atherosclerosis. Cardiovasc Res 2015 doi: 10.1093/cvr/cvv266 [published Online First: 2015/12/10]

20. Sacks HS, Fain JN, Cheema P, et al. Depot-specific overexpression of proinflammatory, redox, endothelial cell, and angiogenic genes in epicardial fat adjacent to severe stable coronary atherosclerosis. Metab Syndr Relat Disord 2011;9(6):433-9. doi: 10.1089/met.2011.0024 [published Online First: 2011/06/18]

21. Takaoka M, Suzuki H, Shioda S, et al. Endovascular injury induces rapid phenotypic changes in perivascular adipose tissue. Arterioscler Thromb Vasc Biol 2010;30(8):1576-82. doi: 10.1161/atvbaha.110.207175 [published Online First: 2010/05/22]

22. Ohyama K, Matsumoto Y, Amamizu H, et al. Association of Coronary Perivascular Adipose Tissue Inflammation and Drug-Eluting Stent-Induced Coronary Hyperconstricting Responses in Pigs: (18)FFluorodeoxyglucose Positron Emission Tomography Imaging Study. Arterioscler Thromb Vasc Biol 2017;37(9):1757-64. doi: 10.1161/atvbaha.117.309843 [published Online First: 2017/07/29]

23. Akoumianakis I, Tarun A, Antoniades C. Perivascular adipose tissue as a regulator of vascular disease pathogenesis: identifying novel therapeutic targets. Br J Pharmacol 2017;174(20):3411-24. doi: 10.1111/bph.13666

24. Zhuge F, Ni Y, Nagashimada M, et al. DPP-4 Inhibition by Linagliptin Attenuates Obesity-Related Inflammation and Insulin Resistance by Regulating M1/M2 Macrophage Polarization. Diabetes 2016;65(10):2966-79. doi: 10.2337/db16-0317

25. Xue Y, Xu X, Zhang XQ, et al. Preventing diet-induced obesity in mice by adipose tissue transformation and angiogenesis using targeted nanoparticles. Proc Natl Acad Sci U S A 2016;113(20):5552-7. doi: $10.1073 /$ pnas. 1603840113

26. Iacobellis G, Lonn E, Lamy A, et al. Epicardial fat thickness and coronary artery disease correlate independently of obesity. Int $J$ Cardiol 2011;146(3):452-4. doi: 10.1016/j.ijcard.2010.10.117 [published Online First: 2010/11/26] 
27. Mahabadi AA, Balcer B, Dykun I, et al. Cardiac computed tomography-derived epicardial fat volume and attenuation independently distinguish patients with and without myocardial infarction. PLOS ONE 2017;12(8)

28. Rosito GA, Massaro JM, Hoffmann U, et al. Pericardial fat, visceral abdominal fat, cardiovascular disease risk factors, and vascular calcification in a community-based sample - The framingham heart study. Circulation 2008;117(5):605-13. doi: 10.1161/circulationaha.107.743062

29. Mahabadi AA, Massaro JM, Rosito GA, et al. Association of pericardial fat, intrathoracic fat, and visceral abdominal fat with cardiovascular disease burden: the Framingham Heart Study. Eur Heart J 2009;30(7):850-56. doi: 10.1093/eurheartj/ehn573

30. McClain J, Hsu F, Brown E, et al. Pericardial Adipose Tissue and Coronary Artery Calcification in the Multi-Ethnic Study of Atherosclerosis (MESA). Obesity 2013;21(5):1056-63. doi: 10.1002/oby.20090

31. Mahabadi AA, Lehmann N, Kalsch H, et al. Association of epicardial adipose tissue with progression of coronary artery calcification is more pronounced in the early phase of atherosclerosis: results from the Heinz Nixdorf recall study. JACC Cardiovasc Imaging 2014;7(9):909-16. doi: 10.1016/j.jcmg.2014.07.002 [published Online First: 2014/09/06]

32. Mahabadi AA, Berg MH, Lehmann N, et al. Association of Epicardial Fat With Cardiovascular Risk Factors and Incident Myocardial Infarction in the General Population. J Am Coll Cardiol 2013;61(13):1388-95. doi: 10.1016/j.jacc.2012.11.062

33. Bos D, Shahzad R, van Walsum T, et al. Epicardial fat volume is related to atherosclerotic calcification in multiple vessel beds. Eur Heart J Cardiovasc Imaging 2015:jev086.

34. Versteylen MO, Takx RAP, Joosen I, et al. Epicardial adipose tissue volume as a predictor for coronary artery disease in diabetic, impaired fasting glucose, and non-diabetic patients presenting with chest pain. Eur Heart J Cardiovasc Imaging 2012;13(6):517-23. doi: 10.1093/ehjci/jes024

35. Hell MM, Ding X, Rubeaux M, et al. Epicardial adipose tissue volume but not density is an independent predictor for myocardial ischemia. J Cardiovasc Comput Tomogr 2016;10(2):141-9. doi: 10.1016/j.jcct.2016.01.009 
36. Bettencourt N, Toschke AM, Leite D, et al. Epicardial adipose tissue is an independent predictor of coronary atherosclerotic burden. Int J Cardiol 2012;158(1):26-32. doi: 10.1016/j.ijcard.2010.12.085 [published Online First: 2011/01/25]

37. Ito T, Suzuki Y, Ehara M, et al. Impact of epicardial fat volume on coronary artery disease in symptomatic patients with a zero calcium score. Int J Cardiol 2013;167(6):2852-8. doi: 10.1016/j.ijcard.2012.07.026 [published Online First: 2012/08/14]

38. Tanami Y, Jinzaki M, Kishi S, et al. Lack of association between epicardial fat volume and extent of coronary artery calcification, severity of coronary artery disease, or presence of myocardial perfusion abnormalities in a diverse, symptomatic patient population: results from the CORE320 multicenter study. Circ Cardiovasc Imaging 2015;8(3):e002676. doi: 10.1161/circimaging.114.002676 [published Online First: 2015/03/11]

39. Gaborit B, Jacquier A, Kober F, et al. Effects of bariatric surgery on cardiac ectopic fat: lesser decrease in epicardial fat compared to visceral fat loss and no change in myocardial triglyceride content. J Am Coll Cardiol 2012;60(15):1381-89.

40. Kim MK, Tomita T, Kim MJ, et al. Aerobic exercise training reduces epicardial fat in obese men. $J$ Appl Physiol 2009;106(1):5-11. doi: 10.1152/japplphysiol.90756.2008

41. Iacobellis G, Singh N, Wharton S, et al. Substantial changes in epicardial fat thickness after weight loss in severely obese subjects. Obesity 2008;16(7):1693-97. doi: 10.1038/oby.2008.251

42. Franssens BT, Visseren FLJ, Nathoe HM, et al. Relation between cardiovascular disease risk factors and epicardial adipose tissue density on cardiac computed tomography in patients at high risk of cardiovascular events. Eur J Prev Cardiol 2017;24(6):660-70.

43. Mazurek T, Kobylecka M, Zielenkiewicz M, et al. PET/CT evaluation of 18F-FDG uptake in pericoronary adipose tissue in patients with stable coronary artery disease: Independent predictor of atherosclerotic lesions' formation? J Nucl Cardiol 2017;24(3):1075-84. doi: 10.1007/s12350-015-0370-6

44. Franssens BT, Visseren FLJ, Nathoe HM, et al. Relation of Epicardial Adipose Tissue Radiodensity to Coronary Artery Calcium on Cardiac Computed Tomography in Patients at High Risk for Cardiovascular Disease. American Journal of Cardiology 2017;119(9):1359-65. 
45. Abazid RM, Smettei OA, Kattea MO, et al. Relation Between Epicardial Fat and Subclinical Atherosclerosis in Asymptomatic Individuals. $J$ Thorac Imaging 2017;32(6):378-82. doi: 10.1097/rti.0000000000000296 [published Online First: 2017/08/18]

46. Ridker PM, Everett BM, Thuren T, et al. Antiinflammatory Therapy with Canakinumab for Atherosclerotic Disease. N Engl J Med 2017 doi: 10.1056/NEJMoa1707914

47. Marwan M, Hell M, Schuhback A, et al. CT Attenuation of Pericoronary Adipose Tissue in Normal Versus Atherosclerotic Coronary Segments as Defined by Intravascular Ultrasound. J Comput Assist Tomogr 2017;41(5):762-67. doi: 10.1097/rct.0000000000000589 [published Online First: 2017/09/16]

48. Ohyama K, Matsumoto Y, Takanami K, et al. Coronary Adventitial and Perivascular Adipose Tissue Inflammation in Patients With Vasospastic Angina. J Am Coll Cardiol 2018;71(4):414-25. doi: 10.1016/j.jacc.2017.11.046

49. Alkhalil M, Edmond E, Edgar L, et al. The relationship of perivascular adipose tissue and atherosclerosis in the aorta and carotid arteries, determined by magnetic resonance imaging. Diab Vasc Dis Res 2018:1479164118757923. doi: 10.1177/1479164118757923

50. Shields KJ, El Khoudary SR, Ahearn JM, et al. Association of aortic perivascular adipose tissue density with aortic calcification in women with systemic lupus erythematosus. Atherosclerosis 2017;262:5561. doi: 10.1016/j.atherosclerosis.2017.04.021 


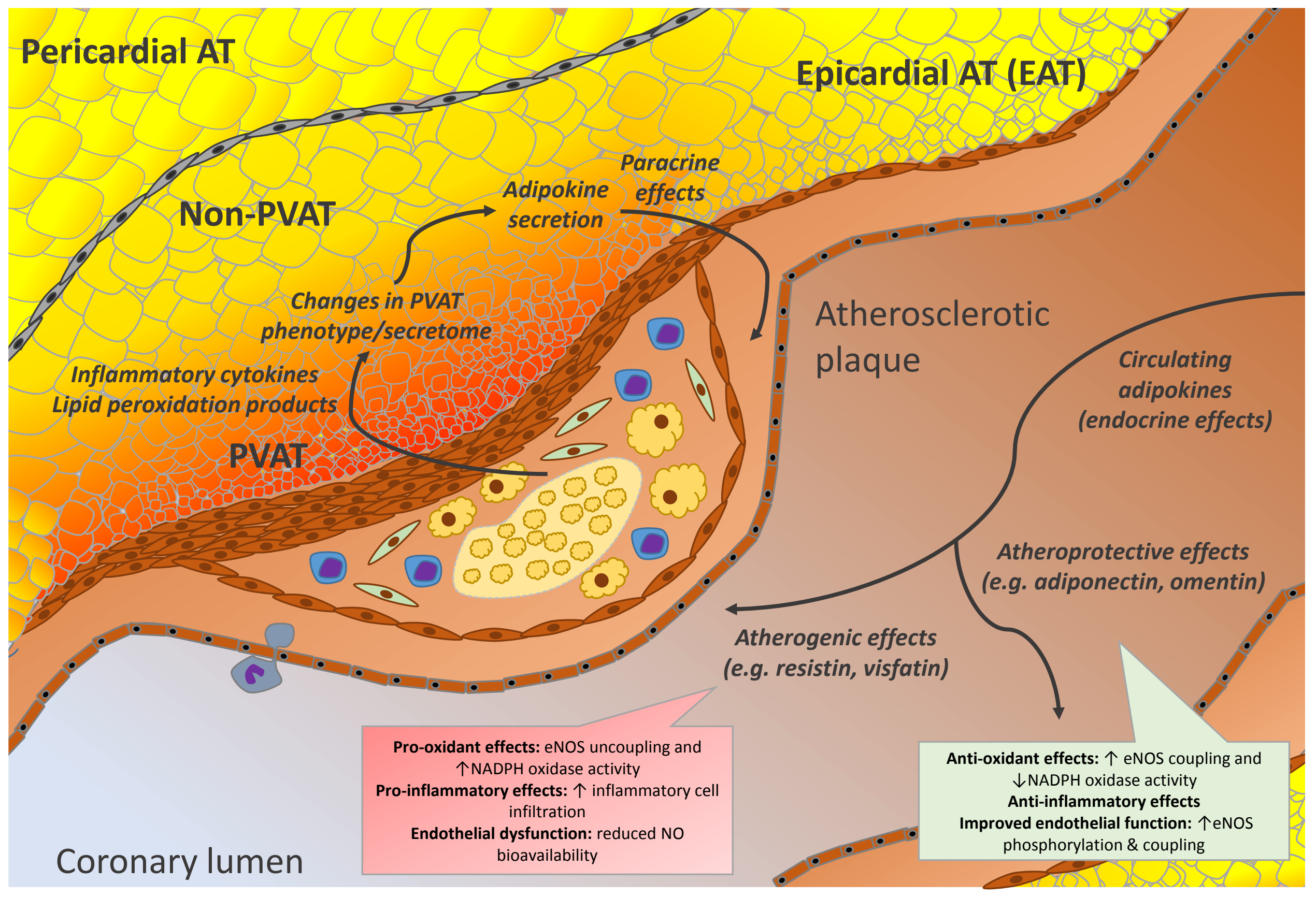

:Leukocytes

: Smooth muscle cells

- Endothelial cells

: Foam cells

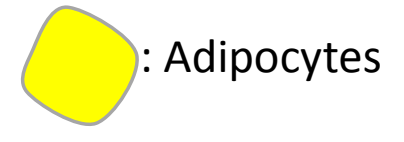


A

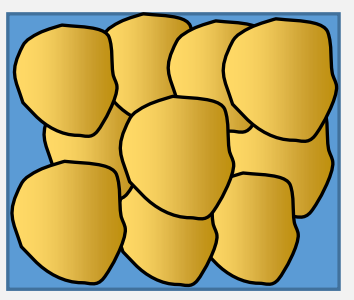

High intracellular lipid content High adipocyte differentiation Larger adipocyte size

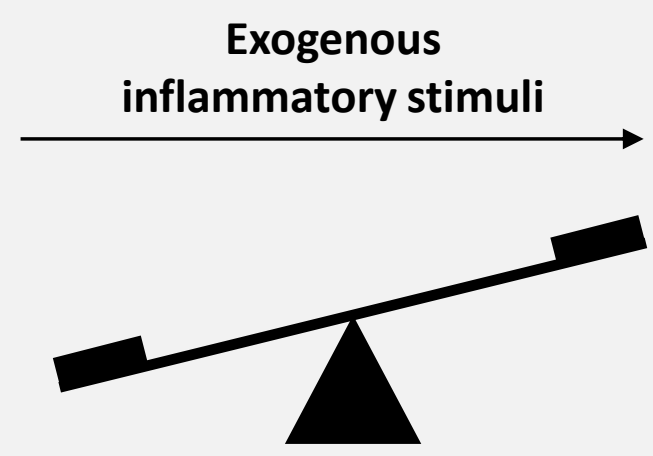

\section{Exogenous} inflammatory stimuli

$-190 \mathrm{HU}$

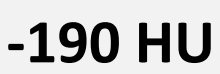

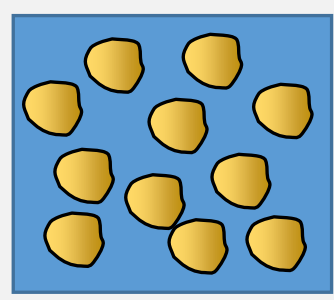

Low intracellular lipid content Poor adipocyte differentiation Small adipocyte size

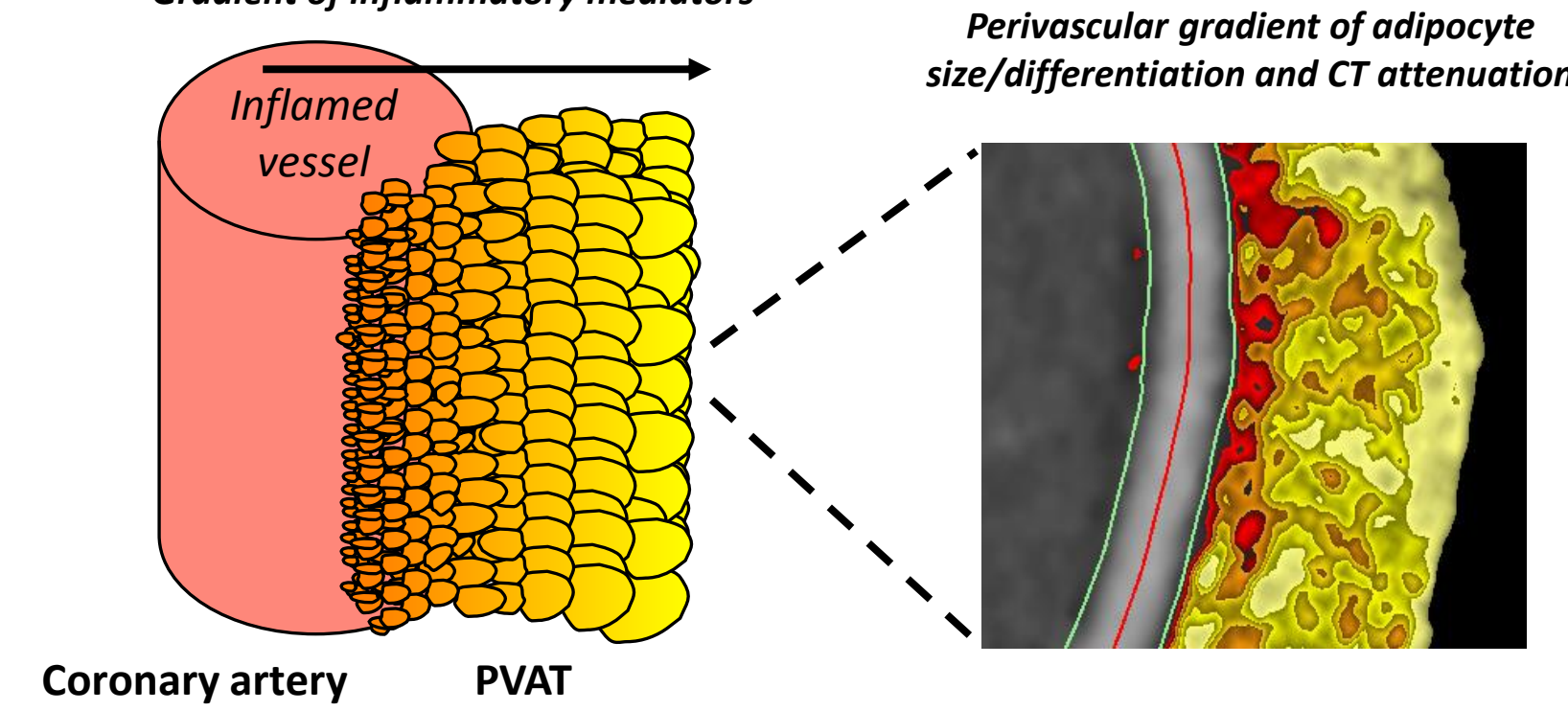

B Gradient of inflammatory mediators

Coronary artery

PVAT

$-30 \mathrm{HU}$

CT attenuation of adipose tissue 


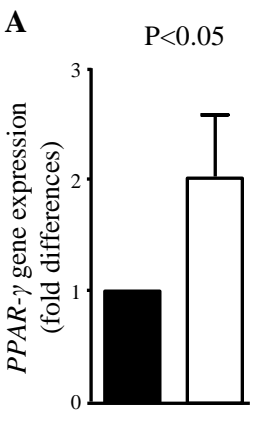

$1 \mathrm{~mm} 20 \mathrm{~mm}$

Distance from RCA
B $\quad \mathrm{P}<0.05$

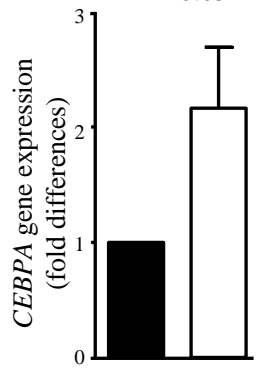

$1 \mathrm{~mm} 20 \mathrm{~mm}$

Distance from RCA

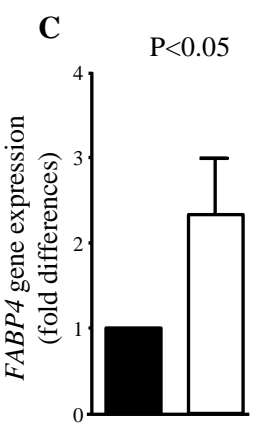

$1 \mathrm{~mm} 20 \mathrm{~mm}$

Distance from RCA
D $\quad \mathrm{P}<0.05$

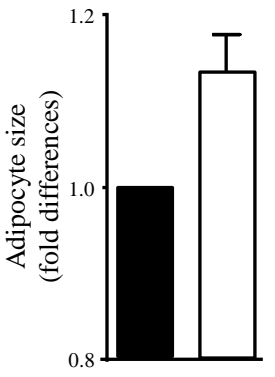

$1 \mathrm{~mm} 20 \mathrm{~mm}$

Distance from RCA
E

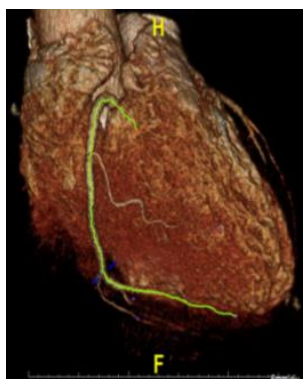

I
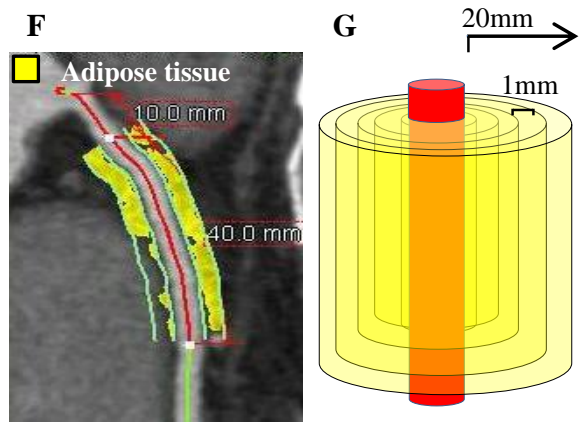

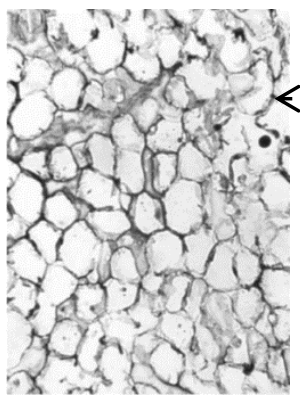

a: $1 \mathrm{~mm}$ from RCA

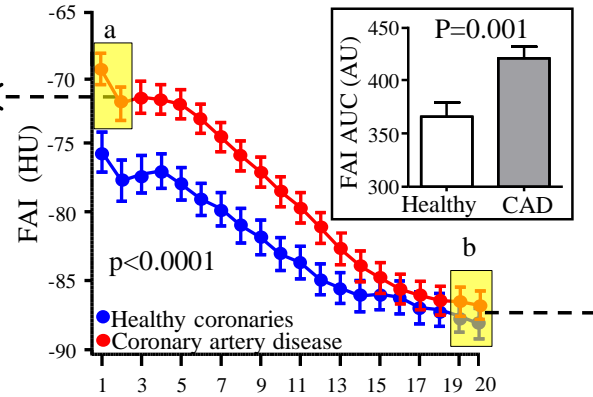

Distance from RCA outer wall (mm)
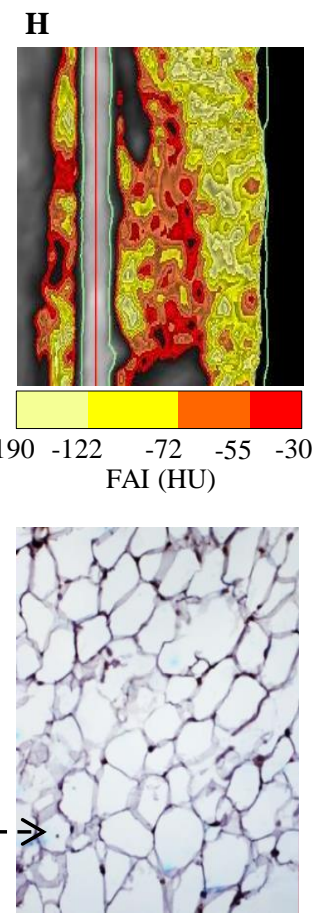

b: $20 \mathrm{~mm}$ from RCA 